OPEN ACCESS

Edited by:

Nadia Caccamo

University of Palermo, Italy

Reviewed by:

Gabriella Pietra,

University of Genoa, Italy

Petra Reinke,

Charité - Universitätsmedizin Berlin,

Germany

*Correspondence:

Francesc Rudilla

frudilla@bst.cat

Specialty section This article was submitted to

T Cell Biology,

a section of the journal

Frontiers in Immunology

Received: 02 August 2019 Accepted: 03 February 2020 Published: 25 February 2020

Citation:

Grau-Vorster M, López-Montañés M, Cantó E, Vives J, Oliver-Vila I, Barba P.

Querol S and Rudilla F (2020)

Characterization of a

Cytomegalovirus-Specific T

Lymphocyte Product Obtained

Through a Rapid and Scalable

Production Process for Use in

Adoptive Immunotherapy.

Front. Immunol. 11:271.

doi: 10.3389/fimmu.2020.00271

\section{Characterization of a} Cytomegalovirus-Specific T Lymphocyte Product Obtained Through a Rapid and Scalable Production Process for Use in Adoptive Immunotherapy

\author{
Marta Grau-Vorster ${ }^{1,2}$, María López-Montañés ${ }^{1,2}$, Ester Cantó ${ }^{1,2}$, Joaquim Vives ${ }^{1,3,4}$, \\ Irene Oliver-Vila ${ }^{1}$, Pere Barba ${ }^{5}$, Sergi Querol ${ }^{1}$ and Francesc Rudilla ${ }^{1,2 *}$ \\ ${ }^{1}$ Cell Therapy Service, Banc de Sang i Teixits, Barcelona, Spain, ${ }^{2}$ Transfusion Medicine Group, Vall d'Hebron Research \\ Institute, Universitat Autònoma de Barcelona, Barcelona, Spain, ${ }^{3}$ Musculoskeletal Tissue Engineering Group, Vall d'Hebron \\ Research Institute (VHIR), Universitat Autònoma de Barcelona, Barcelona, Spain, ${ }^{4}$ Medicine Department, Universitat \\ Autònoma de Barcelona, Barcelona, Spain, ${ }^{5}$ Hematology Department, Hospital Universitari Vall d'Hebron, Universitat \\ Autònoma de Barcelona, Barcelona, Spain
}

Immunosuppressed patients are susceptible to virus reactivation or de novo infection. Adoptive immunotherapy, based on virus-specific T lymphocytes (VST), can prevent or treat viral diseases. However, donor availability, HLA-compatibility restrictions, high costs, and time required for the production of personalized medicines constitute considerable limitations to this treatment. Ex vivo rapid and large-scale expansion of VST, compliant with current good manufacturing practice (cGMP) standards, with an associated cell donor registry would overcome these limitations. This study aimed to characterize a VST product obtained through an expansion protocol transferable to cGMP standards. Antigenic stimulus consisted of cytomegalovirus (CMV) pp65 peptide pool-pulsed autologous dendritic cells (DCs) derived from monocytes. G-Rex technology, cytokines $\mathrm{IL}-2, \mathrm{IL}-7$, and IL-15, and anti-CD3 and anti-CD28 antibodies were used for culture. At day 14 of cell culture, the final product was characterized regarding $T$ cell subsets, specificity, and functionality. The final product, comprised mainly $\mathrm{CD}^{+}$and $\mathrm{CD}^{+}{ }^{+} \mathrm{T}$ lymphocytes (49.2 \pm 24.7 and $42.3 \pm 25.2$, respectively). The culture conditions made it possible to achieve at least a 98.89-fold increase in pp65-specific CD3 ${ }^{+}$IFN- $\gamma^{+}$cells. These cells were specific, as pp65-specific cytotoxicity was demonstrated. Additionally, in complete HLA mismatch and without the presence of pp65, alloreactivity resulted in $<5 \%$ cell lysis. In conclusion, a cGMP scalable process for the generation of a large number of doses of CMV-specific cytotoxic T cells was successfully performed.

Keywords: virus specific T lymphocytes (VST), antigen presenting cells (APC), adoptive immunotherapy, specificity, cytotoxicity, peripheral blood mononuclear cells (PBMC), alloreactivity 


\section{INTRODUCTION}

Immunodeficient patients are susceptible to infection by cytomegalovirus (CMV) and other viruses. Herpesviruses, such as CMV, are often asymptomatic or mild in healthy individuals. Nevertheless, in the context of immunocompromised patients, viral infections can be a severe cause of morbidity and mortality $(1,2)$. CMV infection rates indicate that the virus is common in most of the population and that incidence increases with age (3). The impaired immune systems of immunocompromised patients are unable to eradicate or limit the virus. Antiviral pharmacologic agents are effective against only some of these viruses; their use is costly, associated with significant toxicities and does not provide long-term protection $(4,5)$. Adoptive immunotherapy based on virus-specific $\mathrm{T}$ lymphocytes (VST) is therefore an attractive option, as T lymphocytes can confer long-term protection against the development of viral disease (6-8).

Donor lymphocyte infusion (DLI) is a conventional therapy for leukemia relapse after Hematopoietic Stem Cell Transplantation (HSCT) and it has also shown activity against virus infections in this setting $(9,10)$. But the use of non-specific lymphocytes to treat viral infection has the risk to develop graft-versus-host disease (GvHD) (11). In addition, DLI may not be effective when stem cell donors are seronegative as it is the case in umbilical cord blood transplantation. However, therapeutic alternative based on antigen-specific $\mathrm{T}$ cells is safe and effective, as it does not increase the risk of GvHD and shows overall response rates of $90 \%$ (12). Direct selection with peptide-multimers (13) or the cytokine capture system $(14,15)$ are currently used to obtain VST. Both procedures present certain limitations, such as the challenge of finding an available compatible and seropositive donor, and the amount of final product obtained, which defines the number of doses. While multimer selection presents the disadvantage of being limited to certain HLA types, the cytokine capture system will only select $\mathrm{T}$ cells producing a specific cytokine. Another hurdle of these methodologies is the very low frequency of CMV-specific T cells present in peripheral blood. According to Gamadia et al. (16), the frequency of $\mathrm{CD}^{+}$interferon gamma (IFN- $\gamma$ ) producing cells ranged between 0.18 and $0.80 \%$, with similar observed $\mathrm{CD}^{+}$ IFN- $\gamma^{+}$frequencies.

In order to create a VST bank, the cell expansion protocol must be well-established and must minimize the presence of alloreactive $\mathrm{T}$ cells in the final product, and the expanded $\mathrm{T}$ cell populations must contain both $\mathrm{CD} 8^{+}$and $\mathrm{CD} 4^{+}$cells to ensure an effective response to the infection $(17,18)$.

We describe a process for generating a single preparation of antiviral $\mathrm{T}$ lymphocytes $\left(\mathrm{CD} 4^{+}\right.$and $\mathrm{CD} 8^{+}$) that is consistently specific for immunodominant and subdominant antigens derived from CMV, a frequent cause of post-transplant morbidity or death. This approach uses a standardized mix of peptides focusing on pp65 protein, the major immunodominant CMV antigen, presented by mature monocyte-derived dendritic cells (moDC), and a combination of cytokines to promote the activation, survival, and expansion of $\mathrm{T}$ cells. After a bibliographic search of the media supplements most commonly used for lymphocyte expansion, cytokines IL-2, IL-7, and IL-15 (19-22) were selected for VST activation and expansion.
Protocol optimization focused on reducing production time and maximizing product functionality. We also aimed to generate large amounts of cells to ensure the availability of several doses for a single patient if needed. Importantly, this method is readily adaptable to clinical implementation in compliance with current good manufacturing practice (cGMP) legislation and the product may be used as a safe and effective antiviral agent for patients at high risk of disease due to CMV infection.

\section{MATERIALS AND METHODS \\ PBMC Handling}

Peripheral blood mononuclear cells (PBMC) were collected from the peripheral blood of $9 \mathrm{CMV}^{+}$seropositive healthy donors with donor informed consent and the corresponding approval of the ethics committee (complies with good clinical practice CPMP/ICH/135/95 and Real Decreto 1090/2015). PBMC isolation, cryopreservation, and thawing were performed as described in previous studies (23). Positive serology for CMV IgG was confirmed using chemiluminescence (Abbot, Abbot Park, Illinois, USA). PBMC from each donor were used to obtain CMV-specific VST, moDCs and phytohemagglutinin (PHA) lymphoblasts. The determination of cell concentration was performed by flow cytometry (Perfect-Count Microspheres ${ }^{\mathrm{TM}}$; Cytognos, Salamanca, Spain) or Neubauer chamber counting. The percentage of cell viability was determined either by 7-aminoactinomycin D (7AAD; BD Biosciences, San Jose, California, USA) staining or Trypan Blue (GE Healthcare, USA). Data was analyzed using CellQuest Pro software version 5.2.1 (BD Biosciences).

\section{Obtaining and Pulsing Dendritic Cells}

Freshly isolated PBMC were initially seeded for $2 \mathrm{~h}$ to allow the adherence of monocytes. Non-adherent PBMC were then collected and cryopreserved. Monocytes were cultured for 8 days to obtain mature dendritic cells (DC), as described elsewhere (24). Mature DC were pulsed for $1-2 \mathrm{~h}$ at $37^{\circ} \mathrm{C}, 5 \% \mathrm{CO}_{2}$, with $10 \mu \mathrm{g} / \mathrm{mL}$ of PepTivator ${ }^{\circledR}$ CMV pp65 (Miltenyi Biotec, Bergisch Gladbach, Germany), referred to here as pp65. PepTivator CMV pp65 is based on peptide pools of mainly 15-mer peptides with 11-amino acid (aa) overlap, covering the complete sequence of the pp65 protein of human cytomegalovirus. Pulsed-DC were used for PBMC coculture.

\section{Expansion Protocol}

As shown in Figure 1, thawed PBMC were seeded at 0.25$1.0 \mathrm{E}+06$ cells $/ \mathrm{cm}^{2}$ at a DC:PBMC ratio of $1: 10$ in a G-Rex culture system (Wilson Wolf Manufacturing, New Brighton, $\mathrm{MN}$ ). Fresh medium was composed of Roswell Park Memorial Institute GlutaMAX media (RPMI, Gibco Laboratories, NY, USA) supplemented with $10 \%(\mathrm{v} / \mathrm{v})$ human AB serum (hSerAB) (Banc de Sang i Teixits, Barcelona, Spain). After 5 days of culture, the medium was completely replaced with RPMI $+10 \%$ hSerAB supplemented with IL-2 $120 \mathrm{U} / \mathrm{mL}$ (Miltenyi Biotec), IL-7 4,400 U/mL (R\&D Systems, MN, USA), and IL-15 $80 \mathrm{U} / \mathrm{mL}$ (Miltenyi Biotec). Moreover, monoclonal antibodies anti-CD3 $(1 \mu \mathrm{g} / \mathrm{mL})$ and anti-CD28 $(2 \mu \mathrm{g} / \mathrm{mL})$ were added (Biolegend, San Diego, California, USA). On days 7, 9, 


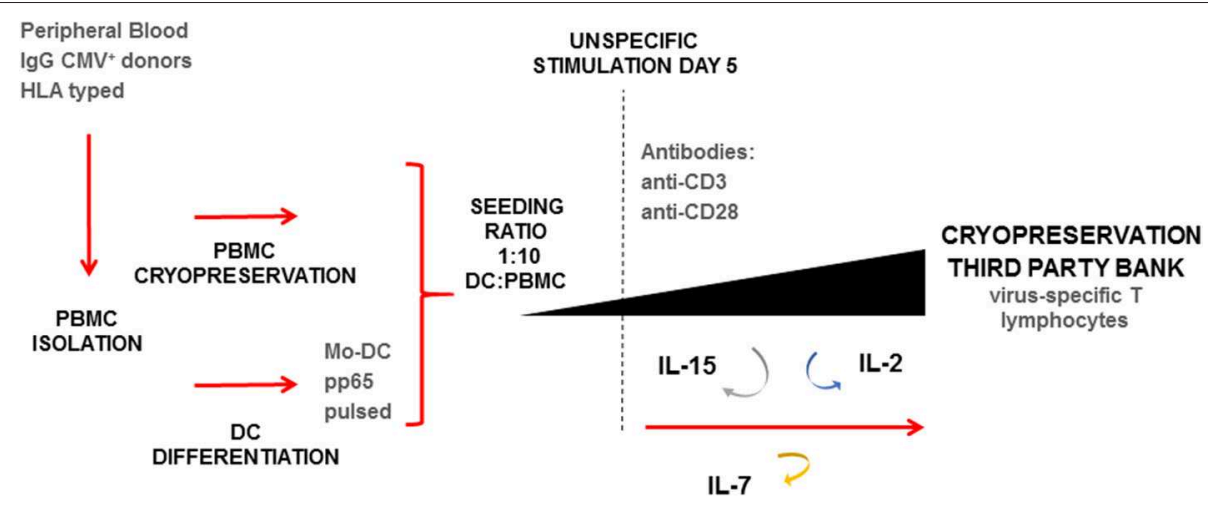

FIGURE 1 | Expansion protocol schematic for the rapid generation of virus-specific T cells (VST). Starting material based on HLA typed peripheral blood lgG ${ }^{+}$for CMV. Isolation of PBMC and selection of monocytes by plastic adherence. Non-adherent PBMC cryopreserved, and attached monocytes differentiated to DC. Seeding performed in a G-Rex device in a ratio 1:10 pp65-pulsed DC:thawed PBMC. Expansion lasted 14-day, with addition at day 5 of anti-CD3 ${ }^{+}$anti-CD28 antibodies, and IL-2, IL-7, IL-15. Renewal of cytokines was performed at days 5, 7, 9, and 12. At day 14 the final product was characterized and cryopreserved.

and 12 , an aliquot of $100-300 \mu \mathrm{L}$ was taken from each culture for cell counting and viability analysis, and fresh medium consisting of $\mathrm{RPMI}+10 \% \mathrm{hSerAB}$ with the addition of IL-2 $120 \mathrm{U} / \mathrm{mL}$, IL-7 4,400 U/mL and IL-15 $80 \mathrm{U} / \mathrm{mL}$ was added. Culture split was performed when cell density reached $8 \mathrm{E}+06$ cells $/ \mathrm{cm}^{2}$.

\section{Obtaining and Pulsing Lymphoblasts}

Fresh or cryopreserved PBMC were adjusted to $2 \mathrm{E}+06$ cells $/ \mathrm{mL}$ and stimulated with PHA $5 \mu \mathrm{g} / \mathrm{mL}$. After $24 \mathrm{~h}$, cells were washed twice with Dulbecco's phosphate-buffered saline solution (PBS, Gibco Laboratories) by centrifugation at $340 \mathrm{~g}$, RT, for $10 \mathrm{~min}$. The solution was then adjusted again to $2 \mathrm{E}+06$ cells $/ \mathrm{mL}$ with RPMI $+10 \% \mathrm{hSerAB}$ and supplemented with IL2 $(100 \mathrm{U} / \mathrm{mL})$. At least $4 \mathrm{~mL}$ of this sample was seeded $(2 \mathrm{~mL} /$ well $)$ in a 24-well plate and the medium was replenished every 24 days. The culture was stored in the incubator at $37^{\circ} \mathrm{C}$, $5 \% \mathrm{CO}_{2}$ as long as G-Rex culture lasted. On the last day of culture, half of the blasts were pulsed with $1 \mu \mathrm{g} / \mathrm{mL}$ of pp65 peptide pool (Miltenyi) for $1-2 \mathrm{~h}$ at $37^{\circ} \mathrm{C} 5 \% \mathrm{CO}_{2}$ and the other half were left non-pulsed. When blasts were used in an allogeneic context, samples were irradiated at $30 \mathrm{~Gy}$ for $15 \mathrm{~min}$.

\section{PBMC Immunophenotype}

For the phenotype analysis, $\mathrm{PBMC}$ were collected and stimulated with $1 \mu \mathrm{g} / \mathrm{mL}$ of pp65 for $6 \mathrm{~h}$ at $37^{\circ} \mathrm{C}, 5 \% \mathrm{CO}_{2}$, at $1 \mathrm{E}+07$ cells $/ \mathrm{mL}$. After $3 \mathrm{~h}$ of stimulation, $1 \mu \mathrm{g} / \mathrm{mL}$ of brefeldin A was added. The cells were then washed and permeabilized using Cytofix/Cytoperm solution (BD). Staining consisted of Live/Dead and monoclonal antibodies: CD45, CD8, CD3, IFN$\gamma$, CD19, CD20, CD56, CD4, FOXP3, CD25, C-C chemokine receptor 7 type (CCR7), and CD45RA (Miltenyi Biotech).

For the analysis of the frequency of HLA$\mathrm{A}^{*}$ 0201/NLVPMVATV $\mathrm{CD}^{+} \mathrm{T}$ cells, APC labeled Pro5 MHC Pentamer (Proimmune, Oxford, UK) was used. Staining was performed according to manufacturers' instructions.
Data acquisition was performed using a Miltenyi MACS Quant flow cytometer. Phenotype was analyzed using FlowJo software v10.

\section{Kinetics of Cytokine Secretion}

Cryopreserved expanded cells were stimulated with CMV pp65 peptide pool (Miltenyi) $50 \mathrm{ng} / \mathrm{mL}$ at a cell concentration of $1 \mathrm{E}+06$ cells $/ \mathrm{mL}$ in a 96 -well plate. Supernatant samples were collected at $0,6,10,24$, and $48 \mathrm{~h}$. All samples were centrifuged at $1,000 \mathrm{~g}$ for $15 \mathrm{~min}$ at $4^{\circ} \mathrm{C}$. To remove aggregates or debris, samples were centrifuged again at $10,000 \mathrm{~g}$ for $10 \mathrm{~min}$ at $4^{\circ} \mathrm{C}$ and stored at $-80^{\circ} \mathrm{C}$ until analysis. Samples were thawed just once and kept on ice before assay. The Bio-Plex Pro ${ }^{\mathrm{TM}}$ Human Cytokine Th1/Th2 (Bio-Rad Laboratories, Hercules, CA, USA) was used for the determination of levels of 9 cytokines: IL-2, IL-4, IL-5, IL-10, IL-12 (p70), IL-13, IFN- $\gamma$, GM-CSF, and TNF- $\alpha$ in a multiplex assay using a Luminex $100 \mathrm{IS}$ analyzer (Luminex Corp. Austin. TX, USA) according to the manufacturer's instructions. Duplicates were tested for each sample. Data analysis was performed using Bioplex Manager Software v6.1 (Bio-Rad Laboratories Inc.).

\section{Enzyme-Linked Immunospot (ELISPOT)}

ELISPOT (MABTECH, Nacka, Sweden) assay was performed in order to determine the specificity of $\mathrm{T}$ cells against $\mathrm{CMV}$ pp65 peptide by means of interferon gamma secretion. Cells were stimulated with $50 \mathrm{ng} / \mathrm{mL}$ pp65 peptide pool (Miltenyi) and left overnight at $2 \mathrm{E}+05$ cells/well. Plates were read in an AID ELISPOT reader (AID GMBH, Strassberg, Germany) following manufacturer's instructions.

\section{CD107a Degranulation Assay}

The final product was incubated for $4 \mathrm{~h}$ at $37^{\circ} \mathrm{C}$ with $10 \% \mathrm{CO}_{2}$ in the presence of monensin $(5 \mathrm{ng} / \mathrm{mL}$, SigmaAldrich, Saint Louis, Missouri, USA) and anti-CD107a FITC (BD Biosciences Pharmingen) with PepTivator ${ }^{\circledR}$ CMV pp65 (Miltenyi). Stimulation with PHA (Sigma-Aldrich) was used as a positive control for degranulation. Unstimulated cells were used as a negative control for degranulation. Data acquisition was 
performed using a MACSQuant instrument (Miltenyi Biotech). Data analysis was performed using FlowJo software v10.

\section{Cytotoxicity Assay Based on Flow Cytometry}

A cytotoxicity assay was performed to detect the manufactured lymphocytes' ability to attack either autologous or allogeneic lymphoblasts with or without presentation of CMV pp65 peptides (Miltenyi). Lymphoblasts were labeled with CFSE (CellTrace $^{\mathrm{TM}}$ CFSE Cell Proliferation Kit; Invitrogen, Waltham, MA, USA), as already reported (23). Allogeneic and autologous non-pulsed lymphoblasts were stained with a high concentration of CFSE $(2.5 \mu \mathrm{M})$, while pp65 peptide pool-pulsed lymphoblasts were labeled with a low concentration of CFSE $(0.25 \mu \mathrm{M})(25)$. Fluorescence loss in the target population was monitored by means of flow cytometry in order to quantify the percentage of specific cytotoxicity (26). Two different ratios of target (T) and effector (E) cells were tested: T:E 1:5 and 1:10, maintaining $1 \mathrm{E}+04$ target cells in both conditions. Triplicates were performed for each condition. Samples were seeded in a 96-well plate and were incubated for 4 and $24 \mathrm{~h}$ of coculture. Data acquisition was performed using a FACS Calibur instrument (BD). Data analysis was performed using FlowJo software v10.

Percentage of specific cytotoxicity was calculated using the ratio of pulsed and non-pulsed target cells without the presence of effector cells as a baseline, according to the following equation (27):

Cell lysis $(\%)=100-\left[100 * \frac{\text { Sample }(\text { CFSElow } / \text { CFSEhigh })}{\text { Baseline }(\text { CFSElow } / \text { CFSEhigh })}\right]$

\section{HLA Typing}

HLA typing for all samples was performed using the next generation sequencing method. Briefly, DNA samples were amplified by means of multiplex PCR using an in-house strategy. After DNA library preparation (GenDX, Utrecht, The Netherlands), pooled samples were paired-end sequenced using a Miseq (Illumina, San Diego, California, USA) following manufacturer's instructions. Data analysis was performed using NGSengine software (GenDX) and IMGT HLA data versions 3.29.0-3.35.0.

\section{Data Analysis}

Microsoft Office Excel ${ }^{\circledR}$ and GraphPad Prism 6 were used for the analysis of the results and for plot generation. Statistical significance was set at: ${ }^{*} p<0.05,{ }^{* *} p<0.01$, and ${ }^{* * *} p<0.001$, Mann-Whitney test.

\section{RESULTS}

\section{Large Expansion of VST in 14-Day Coculture}

Nine VST batches with pp65 specificity were manufactured from nine healthy $\mathrm{CMV}^{+}$donors. We obtained a median of 43.3E +06 cells (min., 4.5E +06 cells; max., 100.1E+06 cells) from an initial seed of $1 \mathrm{E}+06 \mathrm{PBMC}$, representing an average 42.2-fold total expansion within 14 days. The growth kinetics of these cells is shown in Figure 2A. Cells grow slowly up to day 7 and start proliferating exponentially at day 9, with the highest proliferation at days 12-14 of culture (Figure 2A). More specifically, the overall expansion factor of $\mathrm{CD}^{+}$cells for PBMC cocultured with pulsed DC was an average of $49.3 \pm 48.6$ (median, 13.6; $\min , 6.7 ; \max , 127.2 ; n=9$ ) while for PBMCs cocultured with non-pulsed DC, it was an average of $9.6 \pm 6.3$ (median, 8.6; $\min , 4.1 ; \max , 17 ; n=4$ ).

\section{Final Product Mainly Comprising T Cells}

The presence of a variety of cell populations in the final product $\left(\mathrm{CD} 4^{+} \mathrm{T}\right.$ cells, CD8 ${ }^{+} \mathrm{T}$ cells, NK cells, B cells and Treg cells) was evaluated. Expanded cells largely consisted of $\mathrm{CD}^{+}$ $\mathrm{T}$ cells (mean, $96.9 \pm 1.9 \%$ ) containing both $\mathrm{CD}^{+}$(mean, $49.2 \pm 24.7 \%$ ) and $\mathrm{CD}^{+}$(mean, $42.3 \pm 25.2 \%$ ) populations (Figure 2B). Compared to the phenotype of the initial product, significant differences were found in the $\mathrm{CD}^{+}$cell subset, which had largely expanded $(p=0.0004)$, with no changes among the CD ${ }^{+}$cell subset $(p=0.2891)$ but with a significant increase in the $\mathrm{CD}^{+}$cell population $(p=0.0315)$. B cells, NK cells, and Treg cells did not expand and, consequently, their presence decreased to almost undetectable levels in the final product (B cells, $0.3 \pm$ $0.6 \% ; p=0.0013$; NK cells, $0.5 \pm 0.6 \% ; p=0.0225$; and Treg cells, $0.1 \pm 0.1 \% ; p=0.0395)$.

\section{Expanded VST Cells Show Antiviral Specificity Using IFN- $\gamma$}

In order to test the lymphocytes' CMV specificity, cells were reexposed to pp65-pepmix and activation was measured using IFN$\gamma$ intracellular production by flow cytometry. IFN $-\gamma$ secretion of $\mathrm{CD}^{+}, \mathrm{CD}^{+} \mathrm{CD}^{+}$, and $\mathrm{CD}^{+}{ }^{+} \mathrm{CD} 8^{+}$populations is shown in a representative dot plot (Figure 2C). In the independent expansions performed, at day 14 of coculture with pp65-pulsed moDC, the total number of $\mathrm{CD} 3^{+} \mathrm{IFN}-\gamma^{+}, \mathrm{CD} 3^{+} \mathrm{CD} 4^{+} \mathrm{IFN}-$ $\gamma^{+}$, and $\mathrm{CD}^{+} \mathrm{CD} 8^{+} \mathrm{IFN}-\gamma^{+}$cells specific for CMV-pp65 was significantly higher compared to day 0 (Figure 2D) $(p=0.0002)$. Absolute values of $\mathrm{CD}^{+}{ }^{+} \mathrm{IFN}-\gamma^{+}, \mathrm{CD} 4^{+} \mathrm{IFN}-\gamma^{+}$and $\mathrm{CD} 8^{+}$IFN$\gamma^{+}$cells were calculated from day 14 with respect to day 0 . The fold expansion results for $\mathrm{CD}^{+} \mathrm{IFN}-\gamma^{+}$cells were $\mathrm{min}, 98.89$; max, 12,528; and median, 1480.18. The results for $\mathrm{CD} 4^{+} \mathrm{IFN}-\gamma^{+}$ cells were $\min , 60.37$; $\max , 6158.77$; and median, 2082.53. The results for $\mathrm{CD}^{+} \mathrm{IFN}-\gamma^{+}$cells were $\min , 41.51$; $\max , 32146.13$; median, $562.41 ; n=9$.

A summary of the results for 9 donor-independent expansions is shown in Figure 2E. Our data confirmed that, with the expansion system used, the final product contains antigenspecific IFN- $\gamma$-producing $\mathrm{T}$ cells $\left(\mathrm{CD}^{+} \mathrm{IFN}-\gamma^{+} 25.3 \pm\right.$ $16.2 \%)$ with no significant differences between compartments $\left(\mathrm{CD}^{+}{ }^{+} \mathrm{CD} 4^{+}\right.$IFN- $\gamma^{+}, 15.7 \pm 18.1 \%$ CD $^{+} \mathrm{CD}^{+} \mathrm{IFN} \gamma^{+}, 29.3$ $\pm 20.3 \%$; $p=0.3536$ ). Moreover, significant differences were found regarding specificity gain in all subsets after 14-day of culture expansion $\left(\mathrm{CD}^{+} p<0.0001, \mathrm{CD}^{+}{ }^{+} \mathrm{CD} 4^{+} p<0.0001\right.$, and $\left.\mathrm{CD}^{+}{ }^{+} \mathrm{CD} 8^{+} p<0.0001\right)$.

Moreover, we analyzed the frequency of HLA$\mathrm{A}^{*} 0201 / \mathrm{NLVPMVATV}$ pentamer ${ }^{+} \mathrm{CD}^{+} \mathrm{T}$ cells. According to the results, cells expanded with pp65-pulsed DC show a 

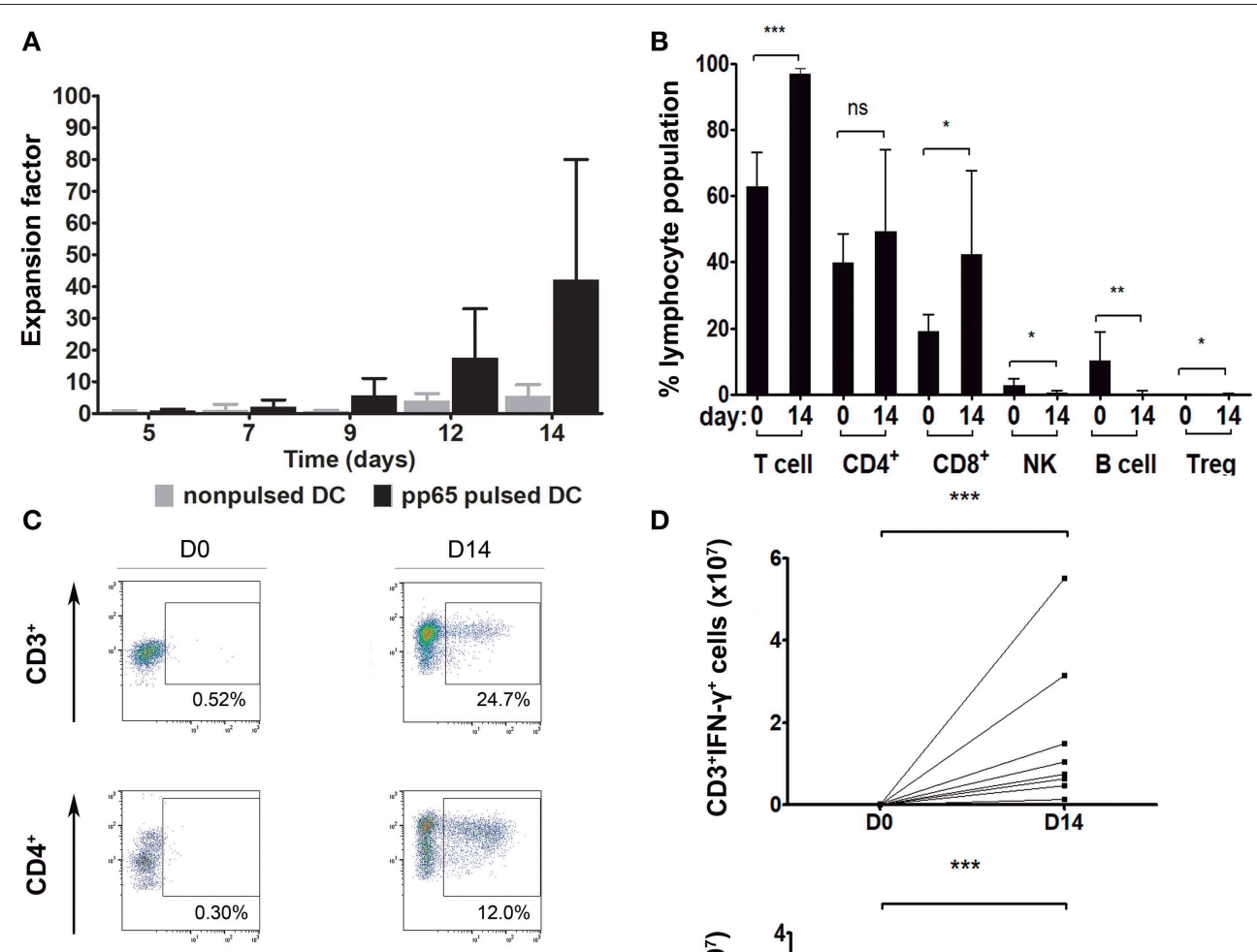

D
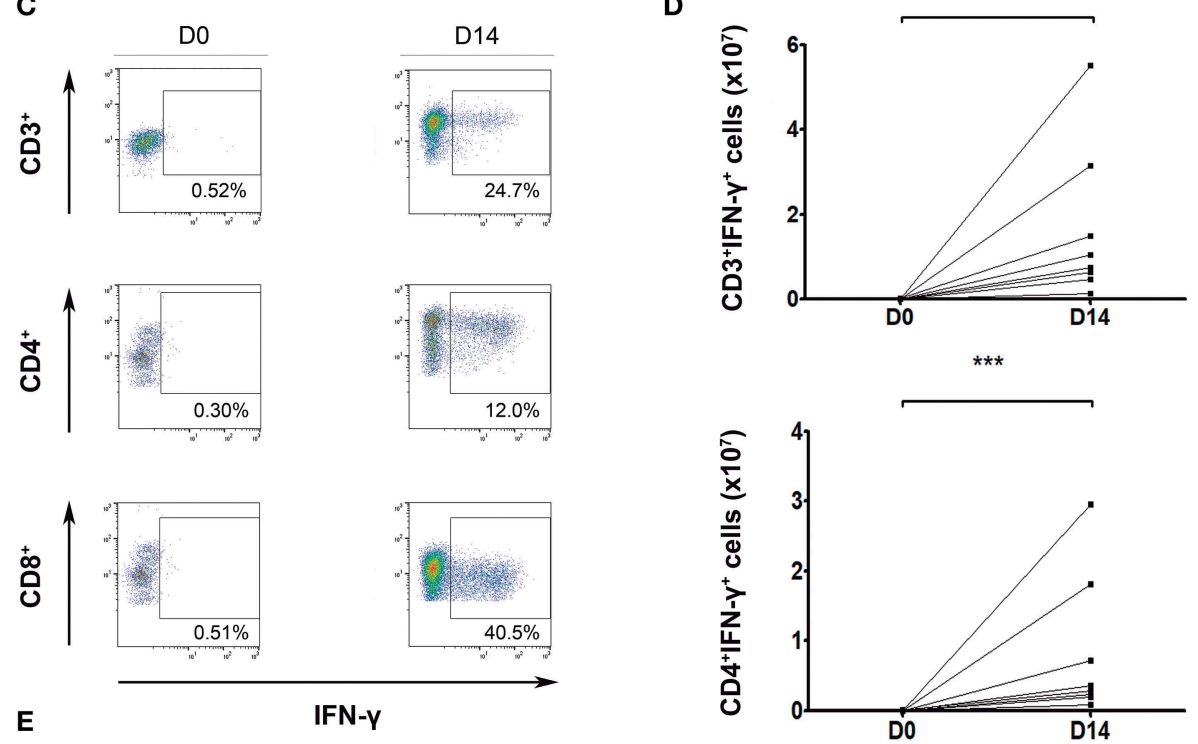

IFN-Y
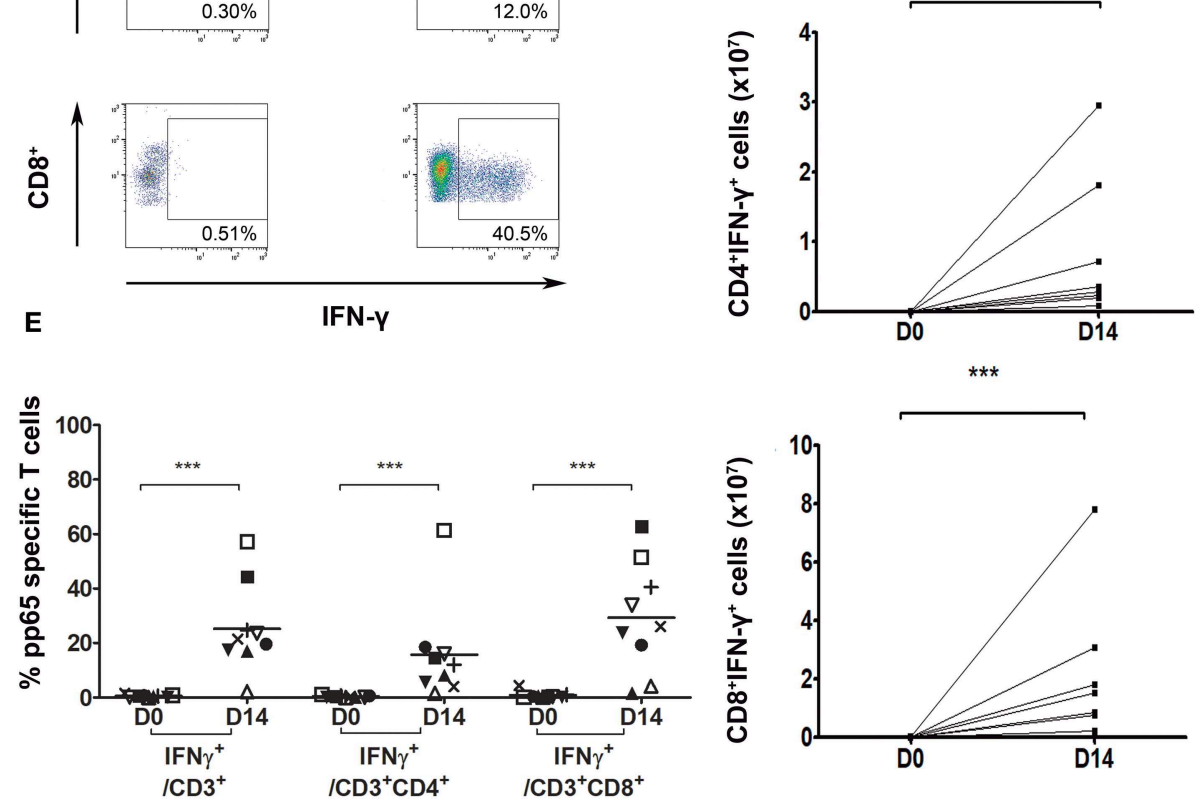

FIGURE 2 | Pp65-specific T cell expansion. (A) Number of total cells at different time points during the 14-day culture. PBMC cocultured with: pp65 peptide pool-pulsed DC (black, $n=9$ ) and nonpulsed DC (gray, $n=4)$ ). (B) Percentage of general cell subpopulations pre- (day 0) and post-expansion (day 14). T cells: CD3 ${ }^{+}$,

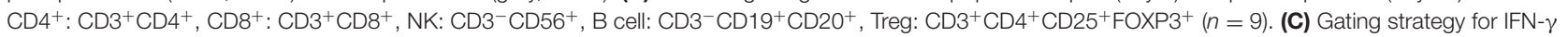
secreting cells from one representative donor. Dot plots show the response of T lymphocytes against pp65 antigen stimulation. (D) Number of VST at day 0 and after the 14-day culture $(n=8)$. (E) Percentage of IFN- $\gamma$ secreting population cells at days 0 and 14 of culture $(n=9) .{ }^{*} p<0.05$, ${ }^{* \star} p<0.01$ and ${ }^{* * *} p<0.001$

(Mann-Whitney test).

higher percentage of antigen specific $\mathrm{CD}^{+} \mathrm{T}$ lymphocytes than pre-expansion cells (Supplementary Figure 4).

\section{CMV-Specific IFN- $\gamma^{+}$T Cells Are Effector Memory T Cells}

To thoroughly characterize the expanded product, $\mathrm{CD}^{+}$, $\mathrm{CD}^{+}{ }^{+} \mathrm{CD} 4^{+}$, and $\mathrm{CD}^{+} \mathrm{CD}^{+}{ }^{+} \mathrm{T}$ cell populations were identified and classified into four different subsets based on the expression of CCR7 and CD45RA markers, following the gating strategy shown in Supplemental Figure 1. Here, naïve $\mathrm{T}$ cells $\left(\mathrm{T}_{\mathrm{N}}\right)$ : $\mathrm{CD} 45 \mathrm{RA}^{+} \mathrm{CCR}^{+}$, central memory $\mathrm{T}$ cells $\left(\mathrm{T}_{\mathrm{CM}}\right)$ : $\mathrm{CD} 45 \mathrm{RA}^{-} \mathrm{CCR}^{+}$, effector memory $\mathrm{T}$ cells $\left(\mathrm{T}_{\mathrm{EM}}\right)$ : $\mathrm{CD} 4 \mathrm{RA}^{-} \mathrm{CCR}^{-}$, and terminally differentiated effector memory $\mathrm{T}$ cells ( $\mathrm{T}_{\mathrm{EMRA}}$ ): $\mathrm{CD} 45 \mathrm{RA}^{+} \mathrm{CCR}^{-}$. 


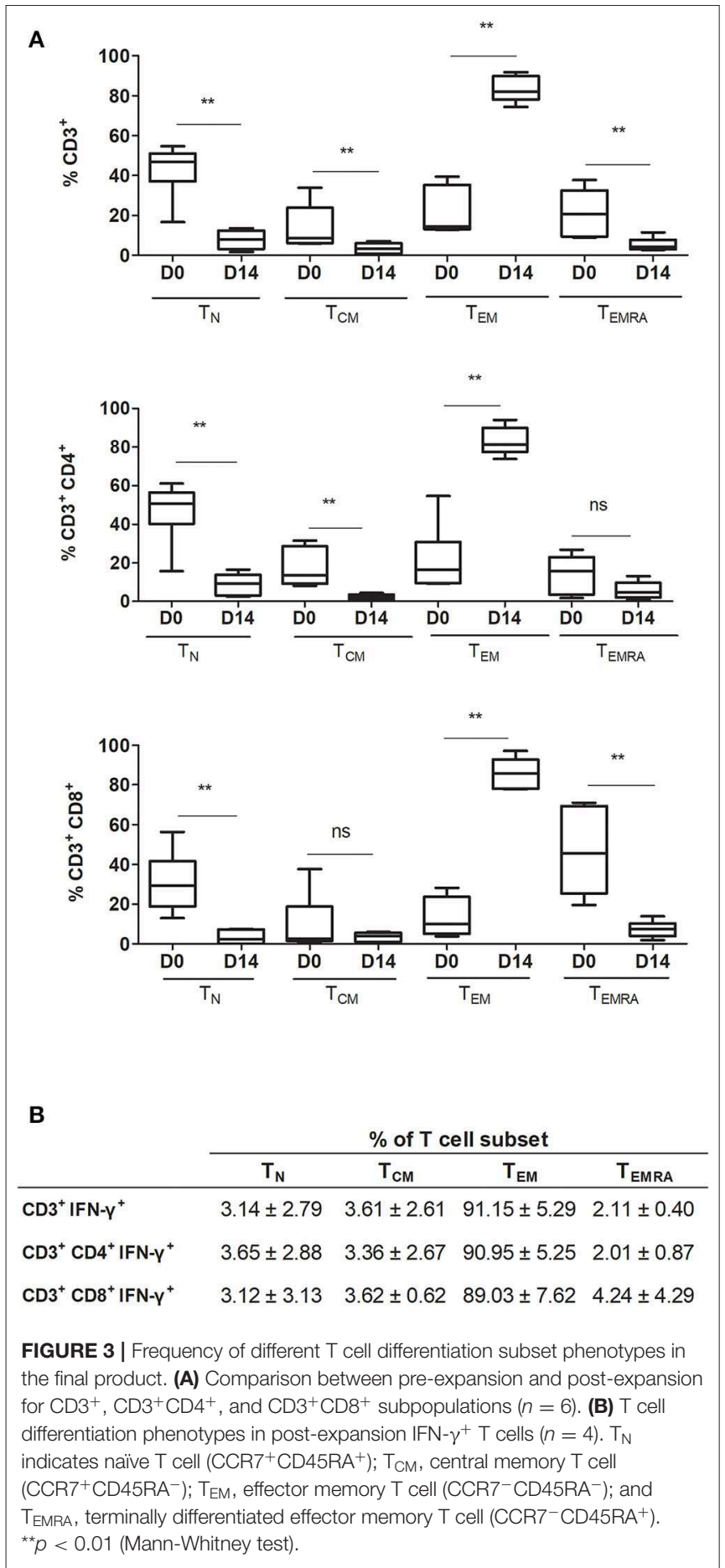

After expansion, the $\mathrm{T}_{\mathrm{N}}$ subset decreased significantly in all $\mathrm{T}$ cell populations $\left(\mathrm{CD}^{+} p=0.0022, \mathrm{CD}^{+}{ }^{+} \mathrm{CD} 4^{+} p=0.0043\right.$, and $\mathrm{CD}^{+}{ }^{+} \mathrm{CD} 8^{+} p=0.0022$ ) (Figure 3A). $\mathrm{T}_{\mathrm{EM}}$ increased significantly in $\mathrm{CD}^{+}, \mathrm{CD}^{+} \mathrm{CD}^{+}$, and $\mathrm{CD}^{+}{ }^{+} \mathrm{CD} 8^{+}$cells $\left(p=0.0050,0.0022\right.$, and 0.0022 , respectively). In general, $\mathrm{CD}^{+}$ subpopulations $\mathrm{T}_{\mathrm{CM}}$ and $\mathrm{T}_{\mathrm{EMRA}}$ decreased significantly after expansion $(p=0.0087)$. For $\mathrm{CD}^{+}{ }^{+} \mathrm{CD} 4^{+}$cells, the $\mathrm{T}_{\mathrm{CM}}$ subset decreased significantly $(p=0.0022)$ and $\mathrm{T}_{\mathrm{EMRA}}$ showed no significant changes $(p=0.1797)$. For $\mathrm{CD} 3^{+} \mathrm{CD} 8^{+}$cells, the $\mathrm{T}_{\mathrm{CM}}$ subset showed no significant changes $(p=0.9372)$ and the $\mathrm{T}_{\mathrm{EMRA}}$ subset showed a significant decrease $(p=0.0022)$.

Interferon gamma, used here as a marker of CMV T cell specificity, was expressed by both $\mathrm{CD}^{+}{ }^{+} \mathrm{CD} 4^{+}$and $\mathrm{CD} 3^{+} \mathrm{CD} 8^{+}$ $\mathrm{T}$ cells. The $\mathrm{T}$ cell subsets expressing IFN- $\gamma$ corresponded overwhelmingly to the $\mathrm{T}_{\mathrm{EM}}$ subset: $\mathrm{CD}^{+}, 91.15 \pm 5.29 \%$; $\mathrm{CD}^{+}{ }^{+} \mathrm{CD} 4^{+}, 90.95 \pm 5.25 \%$; and $\mathrm{CD}^{+}{ }^{+} \mathrm{CD}^{+}, 89.03 \pm 7.62 \%$ (Figure 3B). Moreover, when comparing the phenotype of preexpanded cells, cells expanded with nonpulsed DC, and cells expanded with pp65-pulsed DC, we observed that the main $T$ cell subset in specific expanded cells correspond to $\mathrm{T}_{\mathrm{EM}}$ together with a higher expression of IFN- $\gamma$ expression. Cells expanded with non-pulsed DC and pre-expansion cells, have a lower expression of IFN- $\gamma$ and a higher percentage of $\mathrm{T}_{\mathrm{N}}$ (Supplementary Figure 5). If we focus on the pp65-pulsed DC sample, and analyze the non-responsive cells $\left(\mathrm{CD}^{+} \mathrm{IFN}^{-} \gamma^{-}\right)$, the $\mathrm{T}$ cell subsets are distributed similarly to the responsive cells $\left(\mathrm{CD}^{+}{ }^{+} \mathrm{IFN}-\gamma^{+}\right)$but with a lesser percentage of $\mathrm{T}_{\mathrm{EM}}$, and a higher percentage of other $\mathrm{T}$ cell subsets, including $\mathrm{T}_{\mathrm{N}}$ (Supplementary Figure 6).

Furthermore, the population of expanded cells that expressed PD1 corresponded to the IFN $-\gamma^{+}$population (Supplementary Figure 7).

\section{Functional and Specific Final Product Against pp65 CMV}

Secretion kinetics of Th1 and Th2 cytokines after stimulation with pp65 of 2 cryopreserved batches of expanded cells at different time points $(0,6,10,24$, and $48 \mathrm{~h})$ are shown in Figure 4. Cytokine secretion had high concentrations of IFN- $\gamma$ and TNF- $\alpha$ detected with a secretion peak after $6 \mathrm{~h}$ of stimulation. Furthermore, IL-2 was secreted in a similar manner but in much lower concentrations.

$\mathrm{T}$ cell response to pp65 was also assessed as a potency assay using IFN- $\gamma$ ELISPOT for cryopreserved samples from day 0 and 14-day expanded product. Based on the number of spot forming colonies (SFC), a significant increase $(p=0.0022)$ in reactivity was detected after expansion (Figure 5A). A similar difference in reactivity was observed compared to the control of expanded cells with nonpulsed DC (Supplementary Figure 8).

A CD107a degranulation assay was performed to check the functionality of three final products. The expression of $\mathrm{CD}{ }^{+} \mathrm{CD} 107 \mathrm{a}^{+}$was detected in the presence of CMV pp65 peptide pool (Figure 5B), while only a slight expression was shown when cells were left unstimulated. However, this assay showed high variability between effector cell batches $\left(\mathrm{CD}^{+}{ }^{+} \mathrm{CD} 107 \mathrm{a}^{+} 22.4 \pm 25.71, n=3\right.$, and $\mathrm{CD} 4{ }^{+} \mathrm{CD} 107 \mathrm{a}^{+} 8.67$ $\pm 11.74, n=3$ ) (Supplementary Figure 2).

We took advantage of the cytotoxicity assay to show that our product was able to induce cell death specifically in the target cell population (see gating strategy in Supplemental Figure 3). Both fresh and cryopreserved effector cells induced lysis among peptide-pulsed blasts, in a similar manner (fresh vs. cryopreserved: 4 -h $p=0.7,24-\mathrm{h} p=0.8$ ). This further supports the feasibility of a ready-to-use cryopreserved cell-bank 


\section{A}

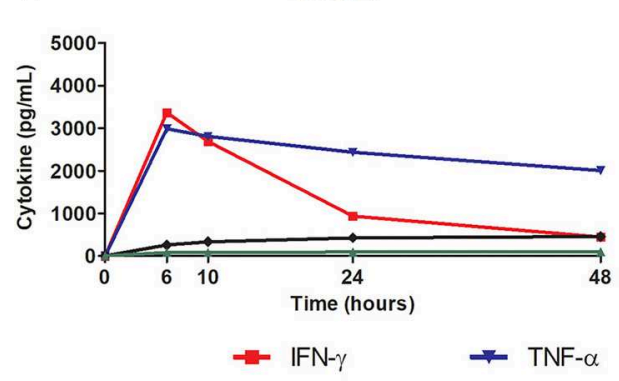

B

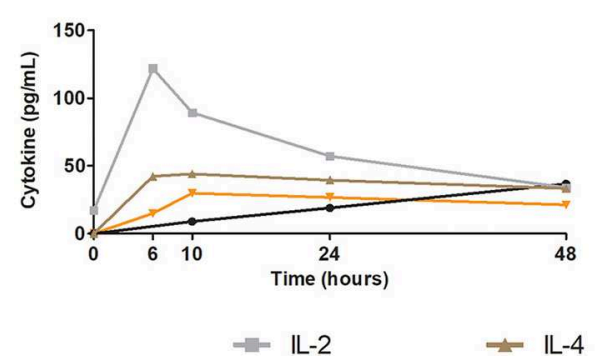

Batch 1

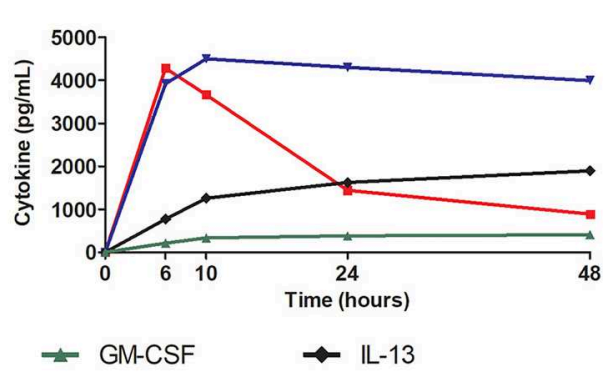

Batch 2

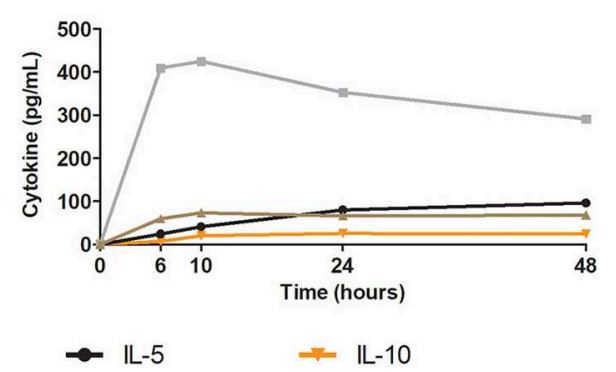

FIGURE 4 | Polyfunctionality of the final thawed product tested using cytokine secretion kinetics after antigenic stimulation. Test performed with Luminex technology. Cytokines tested: IL-2, IL-4, IL-5, IL-10, IL-12 (p70), IL-13, IFN- $\gamma$, GM-CSF, and TNF- $\alpha$. Cells were stimulated with pp65 50 ng/mL at a cell concentration of 1E+06 cells $/ \mathrm{mL}$ in a 96-well plate. Graphs show the kinetics of the secreted cytokines in the supernatant (pg/mL) at each time: 0, 6, 10, 24, and 48 h. (A) Representation of secretion kinetics for cytokines IL-13, IFN- $\gamma$, GM-CSF, and TNF- $\alpha$ from 2 batches of final product. (B) Representation of secretion kinetics for cytokines IL-2, IL-4, $\mathrm{IL}-5$, and IL-10 from 2 batches of final product.

with verified post-thawing functional VSTs (Figure 5C). The expanded product in the presence of autologous blasts pulsed with the peptide resulted in a high percentage of cytotoxicity at both 4 and $24 \mathrm{~h}(23.45 \pm 18.35 \%$ and $68.61 \pm$ $19.76 \%$, respectively).

We leveraged the cytotoxicity assay to assess in vitro safety by testing the alloreactivity and specificity of the final product. Supplementary Tables 1, 2 show, respectively, the high resolution HLA typing for expanded cells [used here as effector [E] cells] and PHA blasts [used here as target [T] cells]. Fresh and cryopreserved expanded cells were cocultured for $24 \mathrm{~h}$ with allogeneic blasts (with 2-3 HLA matches) at ratios of (T:E) 1:5 and 1:10 to test for alloreactivity (Figure 5D), which resulted in cell lysis below $5 \%$ in all cases. However, a correlation between the number of HLA mismatches and percentage of cell lysis was not observed (Pearson correlation: ratio $1: 5, p=0.8211$; ratio $1: 10, p=0.9248$; data not shown). Further characterization was performed by coculture of the final product with allogeneic blasts (2-5 HLA match), either pulsed with pp65 peptide pool or nonpulsed. Expanded T cells specifically induced cell lysis of the allogeneic blasts pulsed with pp65 regardless of the number of HLA matches (Figure 5E). Similarly, a correlation between the number of HLA matches and the percentage of cell lysis was not observed (Pearson test, $p=0.6460$ ).

\section{DISCUSSION}

In recent years, expansion protocols for the creation of VST third-party banks for adoptive immunotherapy have been under development in different centers as an effective and feasible therapy for immunocompromised patients with herpesvirus infections (1, 5, 28-31). We showed a methodology based on ex vivo culture expansion of low-frequency VST to clinical numbers. The process is based on technology that allows scaling up and transfer to cGMP standards. Peripheral blood was used as starting material instead of leukapheresis, in order to facilitate donation compared to the direct selection protocol (32). Physiological antigen presenting cells, DC, are used as potent stimulators for specific $\mathrm{T}$ cell activation, together with an unspecific stimulation on day 5 based on anti-CD3 and anti-CD28 antibodies. Pp65 peptide pool was used to pulse DC for antigen specific stimulation due to being the most immunogenic protein of CMV (33). Nevertheless, immediate early 1 protein (IE-1) specific $\mathrm{T}$ cells have been demonstrated to have a protective effect (34). Therefore, and since the use of both pp65 and IE-1 peptides has been proven successful by Tzannou and colleagues (35), our future approach would be to use both peptides for the generation of CMV specific T cells. The protocol described in this study allowed us to produce in vitro safe and effective VST after a short expansion of only 14day showing an advantage in time over protocols based on longer expansions $(6,33)$. The use of G-Rex technology enabled us to grow cells with a larger volume of media compared to the traditional plastic-based culture and therefore obtain a higher density. The final product was thoroughly characterized for IFN$\gamma$ expression among $\mathrm{CD}^{+}$cells, which are the cells that most express this cytokine, although the $\mathrm{CD} 4^{+}$subset is also essential for orchestrating the immune response $(17,18)$. According to 


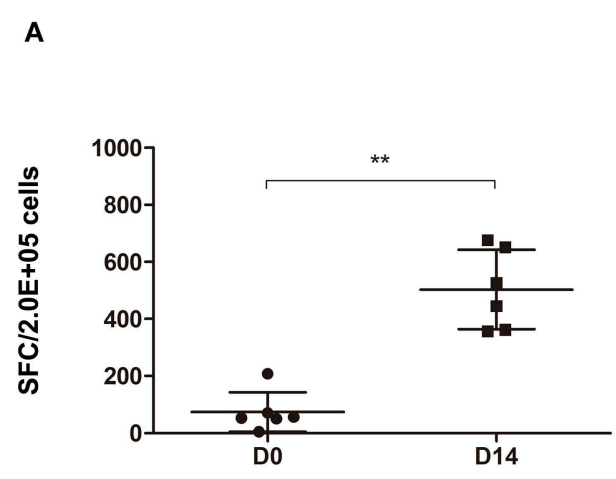

C

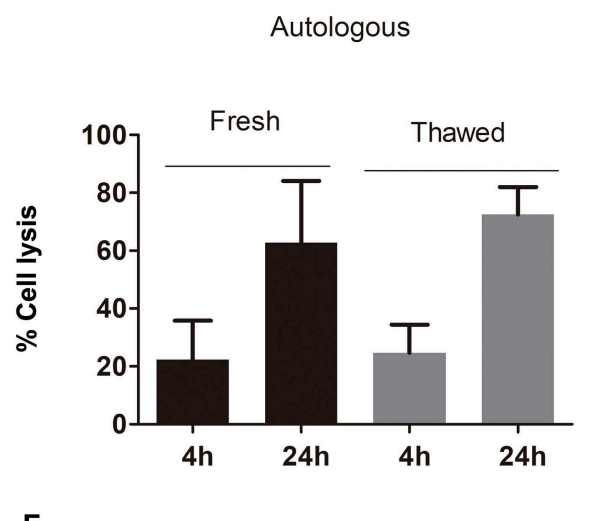

B

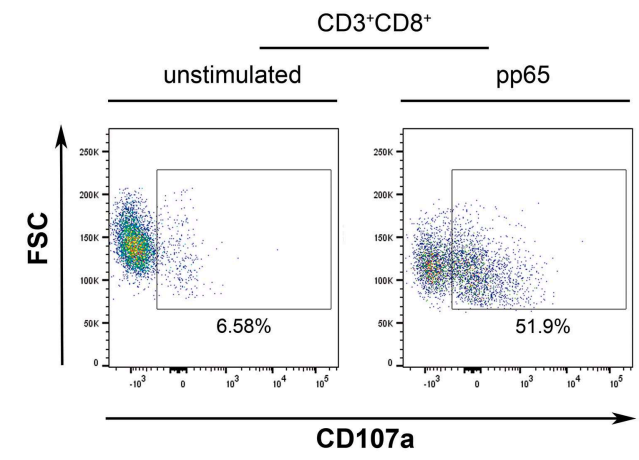

D

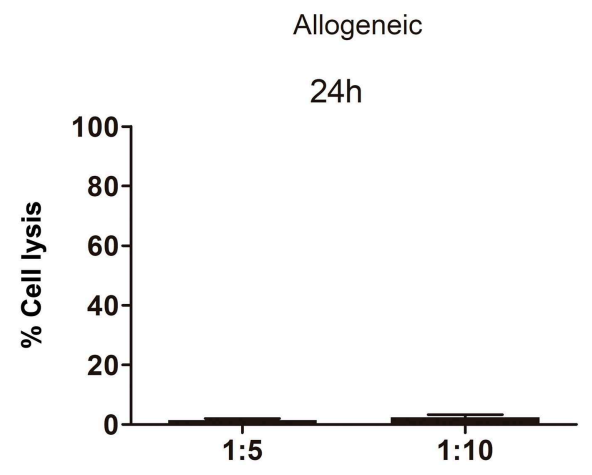

E

\begin{tabular}{ccccc} 
Effector & Target & Match & HLA match & Cell lysis (\%) \\
\hline 1 & II & 2 & $A^{*} 02: 01$, DRB1*07:01 & 9.97 \\
1 & III & 4 & $A^{*} 03: 01, B^{*} 18: 01$, DRB1*07:01, DQB1*03:03 & 10.48 \\
1 & I & 5 & $A^{*} 02: 01, B^{*} 18: 01, C^{*} 05: 01, D R B 1 * 03: 01, D Q B 1^{*} 02: 01$ & 14.47 \\
2 & I & 2 & $A^{*} 02: 01, B^{*} 35: 03$ & 49.52 \\
3 & IV & 2 & $B^{*} 49: 01, C^{*} 07: 01$ & 5.39 \\
3 & V & 3 & $A^{*} 11: 01, C^{*} 07: 01, D R B 1^{*} 13: 02$ & 29.61
\end{tabular}

FIGURE 5 | Potency and functional assays performed with the expanded product. (A) IFN- $\gamma$ ELISPOT for D0 and D14 thawed cells ( $n=6$ ). (B) Example of a degranulation assay $\left(\mathrm{CD} 8^{+} \mathrm{CD} 107 \mathrm{a}^{+}\right)$dot plot for effector cells (VST), unstimulated (left plot) and stimulated with pp65 (right plot). (C) Cytotoxicity assay representation for pp65-pulsed autologous blasts specific lysis [4-h ratio, 1:5 (T:E); $n=3$; 24-h ratio, 1:5 (T:E); $n=2$ ]. (D) Cytotoxicity assay representation for irradiated allogeneic blasts unspecific cell lysis with $2-3$ match $(n=6$, fresh $n=2$, thawed $n=4)$. (E) Cytotoxicity assay representation for effector cells (E): VST, cocultured with target cells (T), pp65-pulsed allogeneic blasts. Percentage of cell lysis calculated from a ratio of $1: 10$ (T:E). ${ }^{\star \star} p<0.01$ (Mann-Whitney test).

the average of 42.2 fold-expansion obtained from the 9 samples, a single blood donation may yield up to 200 doses of $2 \mathrm{E}+07$ $\mathrm{VST} / \mathrm{m}^{2}$, an average fold expansion higher than other expansion protocols; which involves substantial cost reduction compared to other methodologies like direct selection. Enhancement of final product reactivity against CMV pp65 peptides was also confirmed by means of IFN- $\gamma$ ELISPOT assays. The presence of $\mathrm{T}$ helper 1 (Th1) $\mathrm{CD} 4^{+}$cells $\left(\mathrm{CD} 4^{+} \mathrm{IFN}-\gamma^{+}\right)$, present in our final product, is associated with control of persistent infections (36). The proliferation of NK and B cells was prevented and, despite the use of IL-2, regulatory T cells were not present in the final product, thus facilitating the activity of the VSTs generated (37). Since naïve $\mathrm{T}$ cells are potentially alloreactive, it is also interesting that the final product contained low levels of $\mathrm{T}_{\mathrm{N}}$ cells, thereby reducing the probability of GvHD (38). The final product is mainly composed of $\mathrm{T}_{\mathrm{EM}}$, which provide the effector function needed. $\mathrm{T}_{\mathrm{EM}}$ are known to mediate protective memory and they migrate to inflamed peripheral tissues and display immediate effector functions (39). The highest percentage of IFN $-\gamma$ secretion was attributed to this subset, which can therefore rapidly control the infection. Despite the low concentration of $\mathrm{T}_{\mathrm{CM}}$ in the final product, we hypothesize that these cells may engraft and confer long-lasting protection with later differentiation to effector cells upon antigenic stimulation. In vivo $\mathrm{T}$ cell persistence of third-party partially HLA-matched VST has been confirmed by other authors for up to 12 weeks (40). Ex vivo expanded cells 
could also be manufactured, in the case of hematopoietic stem cell transplantation, if available, from the same donor of the transplant, for which rates of functional VST engraftment have been shown to persist for up to 9 years (41). The option of ex vivo expansion on purpose for a single patient or in an autologous context is also conceivable. However, although personalized expansions probably have some advantages, such as choosing the highest HLA matching, this would require manufacturing time that is otherwise absent in a third-party bank.

Final product polyfunctionality was demonstrated by the detection of several secreted cytokines after cell stimulation. Among the inflammatory cytokines tested, we found not only IFN- $\gamma$ after stimulation with pp65 but also high concentrations of TNF- $\alpha$. Products with production of multiple cytokines have been shown to provide a more effective immune response against a pathogen (42).

We showed that the product has the potential to specifically kill pp65 peptide pool-pulsed autologous cells. To emulate allogeneic therapy conditions, we tested pp65-pulsed target cells with 2-3 match with our effector cells. The response varied from the HLA allele matched rather than with the number of HLA matching, in line with findings in the literature that certain pp65 epitopes are HLA restricted and some of them are immunodominant epitopes $(33,43-45)$. Moreover, the results shown by degranulation assays further confirmed that the VST obtained act as antigen-specific effector cells; cells degranulate, and therefore have the capacity to strike pp65 pulsed cells.

As for any other therapy it is essential that our product shows not only efficacy but safety. Alloreactivity assays were performed to characterize the in vitro safety of the product. When testing alloreactivity, we observed that effector cells did not lyse target cells that were not pulsed with the peptide pool, independently of the number of HLA matches. The similar functionality observed for both the fresh and cryopreserved product demonstrates the feasibility of generating a VST bank that maintains the product properties. The lack of correlation observed between HLA matching and specific cell lysis suggests that HLA restriction of immunodominant epitopes is more important than higher HLA compatibility between the donor and the patient in order to induce specific lysis. On the contrary, higher HLA matching would ensure engraftment of donor $\mathrm{T}$ lymphocytes as well as long-term protection. Alloreactivity is an important parameter to consider when using cell therapies as a treatment, as GvHD is one of the major concerns when infusing allogeneic cells. Approaches to avoid GvHD include donor-patient HLA matching and reducing the number of $\mathrm{T}_{\mathrm{N}}$ cells present in the final product. Moreover, alloreactivity in vitro is reduced by ex vivo culturing with virus-specific stimuli, as unspecific cell lysis induced by the expanded cells is $<5 \%$. Our results complement the cytotoxicity assays performed, which ensured the ability of VST to kill target cells without attacking those cells not loaded with the antigen. Some reports indicate that virus-specific memory T cells can exert allo-HLA reactivity (46). Nevertheless, published studies report no increased incidence of GvHD, even when the donor had HLA mismatch, or toxicity related to VST infusion $(1,5,8,15,29,47)$.
Future perspectives include the translation of VST production and validation to cGMP standards. Future prospects also include the generation of other virus-specific T cells, such as EBV, AdV, and BKV, or even multivirus-specific $\mathrm{T}$ cells as shown feasible in the literature (5).

In summary, the use of pp65 peptide pool pulsed DCs and the addition of anti-CD3 and anti-CD28 antibodies in the presence of IL-2, IL-7, and IL-15 resulted in $>98.89$-fold CD3 ${ }^{+}$ IFN- $\gamma^{+}$cell expansion at day 14 . An average of $25.3 \%$ IFN$\gamma$ was achieved in 9 expansions, with very small amounts of $\mathrm{CD}_{6}{ }^{+}, \mathrm{CD}_{19}{ }^{+} / \mathrm{CD} 20^{+}$, or $\mathrm{CD} 4^{+} \mathrm{CD} 25^{+} \mathrm{FOXP}^{+}$cells. $\mathrm{T}_{\mathrm{EM}}$ cell subpopulations were increased after expansion, while $\mathrm{T}_{\mathrm{N}}$ subpopulations were decreased in the final product. Moreover, the reactivity of the product against CMV peptide pp65 was enhanced after short culture expansion tested using the IFN- $\gamma$ ELISPOT assay. In terms of effectivity and in vitro safety, strong cytotoxicity was shown when specific T cells were cocultured with pulsed pp65 autologous blasts. Final product degranulation was confirmed in line with cytotoxicity results. When expanded cells were cultured with non-pulsed allogeneic blasts, a maximum of $5 \%$ lysis was observed. Furthermore, cytotoxicity of expanded cells with pp65-pulsed allogeneic blasts showed specific cell lysis. In conclusion, we have shown a feasible and scalable process that can be easily transferred to cGMP standards and that generates a safe and functional product.

\section{DATA AVAILABILITY STATEMENT}

All datasets generated for this study are included in the article/Supplementary Material.

\section{AUTHOR CONTRIBUTIONS}

Experiments were designed by MG-V, ML-M, IO-V, and FR. Experimental data were generated by MG-V, ML-M, and IO-V, and analysis was performed by MG-V, ML-M, and EC. MG-V, ML-M, SQ, PB, and FR prepared the manuscript. All authors have reviewed the manuscript and have made substantial and intellectual contributions to the work.

\section{FUNDING}

Work in our laboratory was supported by the Spanish Cell Therapy Network (TerCel, file No. RD16/0011/0028), and carried out as part of AdvanceCat with the support of ACCIÓ (Catalonia Trade \& Investment; Catalan government) under the Catalonian ERDF operational program (European Regional Development Fund) 2014-2020. Our laboratory was certified by the Catalan government as a Consolidated Research Group (ref. 2017SGR719).

\section{ACKNOWLEDGMENTS}

The authors would like to thank the current members of Servei de Teràpia Cel-lular (Banc de Sang i Teixits, Barcelona, Spain) for their technical support and advice; members of the 
Histocompatibility and Immunogenetics Laboratory for their technical support; E. Valdivia and N. Martínez, for supplying blood samples; Dr. D. Benítez-Ribas, Dr. Georgina FlórezGrau, and Dr. Alejandro Madrigal for their technical support and advice.

\section{REFERENCES}

1. Withers B, Clancy L, Burgess J, Simms R, Brown R, Micklethwaite K, et al. Establishment and operation of a third party virus-specific T-cell bank within an allogeneic stem cell transplant program. Biol Blood Marrow Transplant. (2018) 24:2433-42. doi: 10.1016/j.bbmt.2018.08.024

2. Sukdolak C, Tischer S, Dieks D, Figueiredo C, Goudeva L, Heuft HG, et al. CMV-, EBV- and ADV-specific T cell immunity: screening and monitoring of potential third-party donors to improve posttransplantation outcome. Biol Blood Marrow Transplant. (2013) 19:1480-92. doi: 10.1016/j.bbmt.2013.07.015

3. Colugnati FA, Staras SA, Dollard SC, Cannon MJ. Incidence of cytomegalovirus infection among the general population and pregnant women in the United States. BMC Infect Dis. (2007) 7:71. doi: 10.1186/1471-2334-7-71

4. Fujita Y, Rooney CM, Heslop HE. Adoptive cellular immunotherapy for viral diseases. Bone Marrow Transplant. (2008) 41:1938. doi: 10.1038/sj.bmt.1705906

5. Papadopoulou A, Gerdemann U, Katari UL, Tzannou I, Liu H, Martinez $\mathrm{C}$, et al. Activity of broad-spectrum $\mathrm{T}$ cells as treatment for AdV, EBV, CMV, BKV, and HHV6 infections after HSCT. Sci Transl Med. (2014) 6:242ra83. doi: 10.1126/scitranslmed.30 08825

6. Mackinnon S, Thomson K, Verfuerth S, Peggs K, Lowdell M. Adoptive cellular therapy for cytomegalovirus infection following allogeneic stem cell transplantation using virus-specific T cells. Blood Cells Mol Dis. (2008) 40:637. doi: $10.1016 /$ j.bcmd.2007.07.003

7. Smith C, Økern G, Rehan S, Beagley L, Lee SK, Aarvak T, et al. Ex vivo expansion of human $\mathrm{T}$ cells for adoptive immunotherapy using the novel Xeno-free CTS immune cell serum replacement. Clin Transl Immunol. (2015) 4:e31. doi: 10.1038/cti.2014.31

8. Gerdemann U, Katari UL, Papadopoulou A, Keirnan JM, Craddock JA, Liu $\mathrm{H}$, et al. Safety and clinical efficacy of rapidly-generated trivirusdirected $\mathrm{T}$ cells as treatment for adenovirus, $\mathrm{EBV}$, and CMV infections after allogeneic hematopoietic stem cell transplant. Mol Ther. (2013) 21:211321. doi: $10.1038 / \mathrm{mt} .2013 .151$

9. Papadopoulos EB, Ladanyi M, Emanuel D, Mackinnon S, Boulad F, Carabasi $\mathrm{MH}$, et al. Infusions of donor leukocytes to treat Epstein-Barr virus-associated lymphoproliferative disorders after allogeneic bone marrow transplantation. N Engl J Med. (1994) 330:1185-91. doi: 10.1056/NEJM199404283301703

10. Kolb HJ, Schattenberg A, Goldman JM, Hertenstein B, Jacobsen N, Arcese W, et al. Graft-versus-leukemia effect of donor lymphocyte transfusions in marrow grafted patients. Blood. (1995) 86:2041-50. doi: 10.1182/blood.V86.5.2041.bloodjournal8652041

11. Scarisbrick JJ, Dignan FL, Tulpule S, Gupta ED, Kolade S, Shaw B, et al. A multicentre UK study of GVHD following DLI: rates of GVHD are high but mortality from GVHD is infrequent. Bone Marrow Transplant. (2015) 50:62-7. doi: 10.1038/bmt.2014.227

12. Houghtelin A, Bollard CM. Virus-specific $T$ cells for the immunocompromised patient. Front Immunol. (2017) 8:1272. doi: 10.3389/fimmu.2017.01272

13. Cobbold M, Khan N, Pourgheysari B, Tauro S, McDonald D, Osman H, et al. Adoptive transfer of cytomegalovirus-specific CTL to stem cell transplant patients after selection by HLA - peptide tetramers. J Exp Med. (2005) 202:379-86. doi: 10.1084/jem.20040613

14. Feuchtinger T, Matthes-Martin S, Richard C, Lion T, Fuhrer M, Hamprecht K, et al. Safe adoptive transfer of virus-specific T-cell immunity for the treatment of systemic adenovirus infection after allogeneic stem cell transplantation. $\mathrm{Br}$ J Haematol. (2006) 134:64-76. doi: 10.1111/j.1365-2141.2006.06108.x

\section{SUPPLEMENTARY MATERIAL}

The Supplementary Material for this article can be found online at: https://www.frontiersin.org/articles/10.3389/fimmu. 2020.00271/full\#supplementary-material

15. Peggs KS, Thomson K, Samuel E, Dyer G, Armoogum J, Chakraverty $\mathrm{R}$, et al. Directly selected cytomegalovirus-reactive donor $\mathrm{T}$ cells confer rapid and safe systemic reconstitution of virus-specific immunity following stem cell transplantation. Clin Infect Dis. (2011) 52:49-57. doi: 10.1093/cid/ ciq042

16. Gamadia LE, Rentenaar RJ, Baars PA, Remmerswaal EB, Surachno S, Weel JF, et al. Differentiation of cytomegalovirus-specific CD8 $+\mathrm{T}$ cells in healthy and immunosuppressed virus carriers. Blood. (2001) 98:75461. doi: 10.1182/blood.V98.3.754

17. Pourgheysari B, Piper KP, McLarnon A, Arrazi J, Bruton R, Clark F, et al. Early reconstitution of effector memory CD4+ CMV-specific T cells protects against CMV reactivation following allogeneic SCT. Bone Marrow Transplant. (2009) 43:853-61. doi: 10.1038/bmt.2008.403

18. Novy P, Quigley M, Huang X, Yang Y. CD4 T cells are required for CD8 T cell survival during both primary and memory recall responses. J Immunol. (2007) 179:8243-51. doi: 10.4049/jimmunol.179.12.8243

19. Hanley PJ, Cruz CR, Savoldo B, Leen AM, Stanojevic M, Khalil M, et al. Functionally active virus-specific $\mathrm{T}$ cells that target $\mathrm{CMV}$, adenovirus, and EBV can be expanded from naive T-cell populations in cord blood and will target a range of viral epitopes. Blood. (2009) 114:195867. doi: 10.1182/blood-2009-03-213256

20. Szmania S, Galloway A, Bruorton M, Musk P, Aubert G, Arthur A, et al. Isolation and expansion of cytomegalovirus-specific cytotoxic $\mathrm{T}$ lymphocytes to clinical scale from a single blood draw using dendritic cells and HLA-tetramers. Blood. (2001) 98:505-12. doi: 10.1182/blood. V98.3.505

21. Krug LM, Dao T, Brown AB, Maslak P, Travis W, Bekele S, et al. WT1 peptide vaccinations induce CD4 and CD8 T cell immune responses in patients with mesothelioma and non-small cell lung cancer. Cancer Immunol Immunother. (2010) 59:1467-79. doi: 10.1007/s00262-010-0871-8

22. Gerdemann U, Keirnan JM, Katari UL, Yanagisawa R, Christin AS, Huye LE, et al. Rapidly generated multivirus-specific cytotoxic $\mathrm{T}$ lymphocytes for the prophylaxis and treatment of viral infections. Mol Ther. (2012) 20:1622-32. doi: 10.1038/MT.2012.130

23. Oliver-Vila I, Ramírez-Moncayo C, Grau-Vorster M, Marín-Gallén $S$, Caminal M, Vives J. Optimisation of a potency assay for the assessment of immunomodulative potential of clinical grade multipotent mesenchymal stromal cells. Cytotechnology. (2018) 70:31-44. doi: 10.1007/s10616-017-0186-0

24. Flórez-Grau G, Cabezón R, Borgman KJE, España C, Lozano JJ, Garcia-Parajo MF, et al. Up-regulation of EP 2 and EP 3 receptors in human tolerogenic dendritic cells boosts the immunosuppressive activity of PGE 2. J Leukoc Biol. (2017) 102:881-95. doi: 10.1189/jlb.2A1216-526R

25. Wonderlich J, Shearer G, Livingstone A, Brooks A, Soloski MJ, Presby MM. Induction and measurement of cytotoxic T lymphocyte activity. Curr Protoc Immunol. (2018) 120:3.11.1-29. doi: 10.1002/cpim.38

26. Berraondo P, Nouzé C, Préville X, Ladant D, Leclerc C. Eradication of large tumors in mice by a tritherapy targeting the innate, adaptive, and regulatory components of the immune system. Cancer Res. (2007) 67:884755. doi: 10.1158/0008-5472.CAN-07-0321

27. Chaoul, N., Fayolle, C., and Leclerc, C. (2016). In vivo OVA-specific cytotoxic CD8+ T cell killing assay. Bio-protocol. 6:e1838. doi: 10.21769/BioProtoc.1838

28. Leen AM, Bollard CM, Mendizabal AM, Shpall EJ, Szabolcs P, Antin JH, et al. Multicenter study of banked third-party virus-specific $\mathrm{T}$ cells to treat severe viral infections after hematopoietic stem cell transplantation Methods. Blood. (2014) 121:5113-24. doi: 10.1182/blood-2013-02-486324

29. Barker JN, Doubrovina E, Sauter C, Jaroscak JJ, Perales MA, Doubrovin M, et al. Successful treatment of EBV-associated posttransplantation lymphoma after cord blood transplantation using third-party EBV-specific cytotoxic 
T lymphocytes. Blood. (2010) 116:5045-9. doi: 10.1182/blood-2010-04281873

30. Wilkie GM, Taylor C, Jones MM, Burns DM, Turner M, Kilpatrick D, et al. Establishment and characterization of a bank of cytotoxic T lymphocytes for immunotherapy of Epstein-Barr virus-associated diseases. J Immunother. (2004) 27:309-16. doi: 10.1097/00002371-200407000-00007

31. Haque T, Wilkie GM, Jones MM, Higgins CD, Urquhart G, Wingate P, et al. Allogeneic cytotoxic T-cell therapy for EBV-positive posttransplantation lymphoproliferative disease: results of a phase 2 multicenter clinical trial. Blood. (2007) 110:1123-32. doi: 10.1182/blood-2006-12063008

32. Tischer S, Priesner C, Heuft HG, Goudeva L, Mende W, Barthold M, et al. Rapid generation of clinical-grade antiviral T cells: selection of suitable T-cell donors and GMP-compliant manufacturing of antiviral T cells. J Transl Med. (2014) 12:336. doi: 10.1186/s12967-014-0336-5

33. Koehne G, Hasan A, Doubrovina E, Prockop S, Tyler E, Wasilewski G, et al. Immunotherapy with donor $\mathrm{T}$ cells sensitized with overlapping pentadecapeptides for treatment of persistent cytomegalovirus infection or viremia. Biol Blood Marrow Transplant. (2015) 21:1663-78. doi: 10.1016/j.bbmt.2015.05.015

34. Bunde T, Kirchner A, Hoffmeister B, Habedank D, Hetzer R, Cherepnev G, et al. Protection from cytomegalovirus after transplantation is correlated with immediate early 1-specific CD8 T cells. J Exp Med. (2005) 201:10316. doi: $10.1084 /$ jem.20042384

35. Tzannou I, Watanabe A, Naik S, Daum R, Kuvalekar M, Leung $\mathrm{KS}$, et al. "Mini" bank of only 8 donors supplies CMV-directed $\mathrm{T}$ cells to diverse recipients. Blood Adv. (2019) 3:2571-80. doi: 10.1182/bloodadvances.2019000371

36. Snell LM, Osokine I, Yamada DH, De la Fuente JR, Elsaesser HJ, Brooks DG. Overcoming CD4 Th1 cell fate restrictions to sustain antiviral CD8 T cells and control persistent virus infection. Cell Rep. (2016) 16:3286-96. doi: 10.1016/j.celrep.2016.08.065

37. Dittmer U, He H, Messer RJ, Schimmer S, Olbrich AR, Ohlen $\mathrm{C}$, et al. Functional impairment of $\mathrm{CD} 8+\mathrm{T}$ cells by regulatory $\mathrm{T}$ cells during persistent retroviral infection. Immunity. (2004) 20:293-303. doi: 10.1016/S1074-7613(04)00054-8

38. Distler E, Bloetz A, Albrecht J, Asdufan S, Hohberger A, Frey M, et al. Alloreactive and leukemia-reactive $\mathrm{T}$ cells are preferentially derived from naïve precursors in healthy donors: implications for immunotherapy with memory $\mathrm{T}$ cells. Haematologica. (2011) 96:1024-32. doi: 10.3324/haematol.2010.037481

39. Sallusto F, Geginat J, Lanzavecchia A. Central memory and effector memory $\mathrm{T}$ cell subsets: function, generation, and maintenance. Annu Rev Immunol. (2004) 22:745-63. doi: 10.1146/annurev.immunol.22.012703. 104702
40. Tzannou I, Papadopoulou A, Naik S, Leung K, Martinez CA, Ramos $\mathrm{CA}$, et al. Off-the-shelf virus-specific $\mathrm{T}$ cells to treat $\mathrm{BK}$ virus, human herpesvirus 6, cytomegalovirus, epstein-barr virus, and adenovirus infections after allogeneic hematopoietic stem-cell transplantation. J Clin Oncol. (2017) 35:3547-57. doi: 10.1200/JCO.2017.73.0655

41. Heslop HE, Slobod KS, Pule MA, Hale GA, Rousseau A, Smith CA, et al. Long-term outcome of EBV-specific T-cell infusions to prevent or treat EBVrelated lymphoproliferative disease in transplant recipients. Blood. (2010) 115:925-35. doi: 10.1182/blood-2009-08-239186

42. Foley JF. Polyfunctional $T$ cells. Sci Signal. (2012) 5:ec42. doi: 10.1126/scisignal.2002929

43. Kondo E, Akatsuka Y, Kuzushima K, Tsujimura K, Asakura S, Tajima K, et al. Identification of novel CTL epitopes of CMV-pp65 presented by a variety of HLA alleles. Blood. (2004) 103:630-8. doi: 10.1182/blood-2003-03-0824

44. Slezak SL, Bettinotti M, Selleri S, Adams S, Marincola FM, Stroncek DF. CMV pp65 and IE-1 T cell epitopes recognized by healthy subjects. J Transl Med. (2007) 5:17. doi: 10.1186/1479-5876-5-17

45. Lehmann PV, Suwansaard M, Zhang T, Roen DR, Kirchenbaum GA, Karulin $\mathrm{AY}$, et al. Comprehensive evaluation of the expressed CD8+ T cell epitope space using high-throughput epitope mapping. Front Immunol. (2019) 10:655. doi: $10.3389 /$ fimmu.2019.00655

46. Amir AL, D’Orsogna LJ, Roelen DL, van Loenen MM, Hagedoorn RS, de Boer $\mathrm{R}$, et al. Allo-HLA reactivity of virus-specific memory $\mathrm{T}$ cells is common. Blood. (2010) 115:3146-57. doi: 10.1182/blood-2009-07-234906

47. Bollard CM, Heslop HE. T cells for viral infections after allogeneic hematopoietic stem cell transplant. Blood. (2016) 127:3331-40. doi: 10.1182/blood-2016-01-628982

Conflict of Interest: PB declares having received honoraria from Amgen, Celgene, Gilead, Incyte, Jazz Pharmaceuticals, MSD, Novartis, Pfizer and Roche, not related with the present article. PB has received funding from the Carlos III FIS16/01433 Health Institute, Asociación Española contra el Cáncer (Ideas Semilla 2019) and a PERIS 2018-2020 grant from the Generalitat de Catalunya (BDNS357800).

The remaining authors declare that the research was conducted in the absence of any commercial or financial relationships that could be construed as a potential conflict of interest.

Copyright @ 2020 Grau-Vorster, López-Montañés, Cantó, Vives, Oliver-Vila, Barba, Querol and Rudilla. This is an open-access article distributed under the terms of the Creative Commons Attribution License (CC BY). The use, distribution or reproduction in other forums is permitted, provided the original author(s) and the copyright owner(s) are credited and that the original publication in this journal is cited, in accordance with accepted academic practice. No use, distribution or reproduction is permitted which does not comply with these terms. 